\title{
One of My Favorite Judges: Constitutional InTERPRETATION, DEMOCRACy AND ANTONIN SCALIA
}

\author{
James Allan* \\ University of Queensland
}

\begin{abstract}
In this article the author explains why Antonin Scalia was one of his favourite judges. It starts by excerpting some of Justice Scalia's most biting and funny comments, both from judicial and extra-judicial sources. Then it explains the attractions of an originalist approach to constitutional interpretation, though arguing that the intentionalist strain is preferable to Scalia's 'original public meaning' or 'new originalism' approach. Finally, it argues that within the confines of a constitutional structure with an entrenched bill of rights, Scalia was a strong proponent of democratic decision-making to resolve key social policy decisions, unlike many other top judges.
\end{abstract}

\section{CONTENTS}

I. Blunt And Biting...............................................................................2 27

II. Constitutional Interpretation: Scalia the Originalist .............................. 32

III. Scalia and the Scope for Democratic Decision-Making...........................38

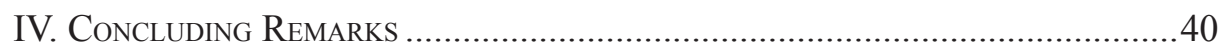

* Garrick Professor of Law, T.C. Beirne School of Law, University of Queensland 
It is best to start by making it clear that on some big issues I differed with the views of former U.S. Supreme Court Justice Antonin Scalia. For instance, I am a critic of bills of rights, be they of the entrenched, constitutionalized United States and Canadian varieties or of the statutory United Kingdom and New Zealand varieties. ${ }^{1}$ By contrast, Justice Antonin Scalia supported the U.S.-style bill of rights that he was regularly called upon to interpret. ${ }^{2}$ Furthermore, I am an 'Original Intended Meaning' ('OIM') originalist, the sort that thinks it is authors' intentions that count, that provide the legitimate and authoritative external standards that pointof-application interpreters ought to seek and that can constrain those interpreters in a way that 'living tree/living Constitution' and 'moral' interpretations never can. Justice Scalia rejected that sort of OIM originalism, sometimes quite sharply, ${ }^{3}$ in favor of searching for what a well-educated and knowledgeable person at the time would have taken the words to mean. Scalia's version of originalism is known as 'textualism' or as 'Original Public Meaning' or 'OPM' or 'new' originalism.

I mention those differences, indeed will come back to them below, for the sake of providing the reader with a bit of perspective on what follows. Bear them in mind because in big picture terms in this article I come to praise Antonin Scalia, not to bury him. In fact Scalia was (and is) one of my favorite judges. As many readers will realize, that is not a sentiment that is or was widely held by law professors in the United States. ${ }^{4}$ And it was probably even less widely held by legal academics in

\footnotetext{
I have criticized bills of rights at length and in a host of contexts. For a selected few instances see e.g., James Allan, Bills of Rights and Judicial Power-A Liberal's Quandary? 16 Oxford J. Leg. Stud. 337 (1996); James Allan, Rights, Paternalism, Constitutions and Judges, in Litigating Rights: Perspectives from Domestic and International Law 29 (Grand Huscroft \& Paul Rishworth eds., 2002); James Allan, Oh That I Were Made Judge in the Land, 30 Fed. L. Rev. 561 (2002); James Allan, A Modest Proposal, 23 Oxford J. Leg. Stud. 197 (2003); James Allan, An Unashamed Majoritarian, 27 Dal. L. J. 537 (2004); James Allan and Grant Huscroft, Rights Internationalism Coming Home to Roost? 43 San Diego L. Rev. 1 (2006); James Allan, Portia, Bassanio or Dick the Butcher? Constraining Judges in the Twenty-First Century, 17 KING's. L. J. 1 (2006); James Allan, Jeremy Waldron and the Philosopher's Stone, 45 SAn Diego L. Rev. 133 (2008); James Allan, Meagher's Mischaracterisations of Majoritarianism, 20 KING'S L.
} J. 115 (2009); James Allan, Democracy in Decline (2014).

2 But the support was qualified. Yes, Scalia supported the U.S. Bill of Rights but maintained that the rights enshrined in it were only guaranteed by the structure of government established in the Constitution: 'Every tin horn dictator in the world today, every president for life, has a Bill of Rights. That's not what makes us free; if it did, you would rather live in Zimbabwe. But you wouldn't want to live in most countries in the world that have a Bill of Rights. What has made us free is our Constitution. Think of the word "constitution"; it means structure [...] The genius of the American constitutional system is the dispersal of power. Once power is centralized in one person, or one part [of government], a Bill of Rights is just words on paper.' Justice Antonin Scalia, Address at the Federalist Society (May 8, 2015).

3 See Justice Antonin Scalia, Common-Law Courts in a Civil-Law System: The Role of United States Federal Courts in Interpreting the Constitution and Laws, in A MATTER OF InTERPRETATION (Amy Gutmann ed., 1998).

4 Jeremy Waldron, before twice quoting Justice Scalia at length, obliquely, mockingly and disapprovingly refers to this widespread dislike of Scalia's views in the U.S. legal academy by saying '(It is time to roll your eyes now and pay no attention for a few minutes, because I am going to quote Justice Antonin Scalia and quote him at length.)' See Jeremy Waldron, The Core of the Case Against Judicial Review, 115 Yale L. J. 1346, 1390 (2006). 
my native Canada, or in the U.K., or in New Zealand, or in Australia. Justice Scalia was despised by many law professors in the Anglo-American world and his views were thoroughly rejected by more still. Not me though. As a law professor who has worked now for 11 years in Australia, and for a decade before that in New Zealand, with teaching sabbaticals in the U.S. and Canada, I am quite partial to the man, and to his jurisprudence. As I said, he is one of my favorite judges.

The goal of this article is to give you an idea of why that is, why this nonAmerican law professor who disagreed with him on a couple of big issues might nevertheless have that view. I will consider it a bonus if, for a reader or two, the good that Scalia did is not interred with his bones.

\section{BLUNT AND BITING}

You cannot get a sense of Scalia as a judge unless you have some idea of how blunt and biting and downright funny he could be. This is a quality I very much like. Start with a few examples from his judicial opinions on the top U.S. court:

"It is one of the unhappy incidents of the federal system that a selfrighteous Supreme Court, acting on its members' personal view of what would make a "more perfect Union" (a criterion only slightly more restrictive than a "more perfect world") can impose its own favored social and economic dispositions nationwide."

"Words no longer have meaning if an Exchange that is not established by a State is 'established by a State'."

"We should start calling this law SCOTUScare ... [T]his Court's two decisions on the Act will surely be remembered through the years ... And the cases will publish forever the discouraging truth that the Supreme Court of the United States favors some laws over others, and is prepared to do whatever it takes to uphold and assist its favorites."”

[Responding to Justice Anthony Kennedy, Scalia indicated that if he had written such nonsense he would]

"hide [his] head in a bag. The Supreme Court of the United States has descended from the disciplined legal reasoning of John Marshall and Joseph Story to the mystical aphorisms of the fortune cookie."

"The [majority] opinion is couched in a style that is as pretentious as its content is egotistic. It is one thing for separate concurring or dissenting

\footnotetext{
United States v. Virginia, 518 U.S. 515, 601 (Scalia, J.) (1996).

King v. Burwell, 576 U.S. _, 2 (Scalia, J.) (2015).

Id. at 21 .

8 Obergefell v. Hodges, 576 U.S. _, 7, 22 (Scalia, J.) (2015).
} 
opinions to contain extravagances, even silly extravagances, of thought and expression; it is something else for the official opinion of the Court to do so."

"If it were impossible for individual human beings (or groups of human beings) to act autonomously in effective pursuit of a common goal, the game of soccer would not exist." 10

"If one assumes, however, that the PGA TOUR has some legal obligation to play classic, Platonic golf - and if one assumes the correctness of all the other wrong turns the Court has made to get to this point - then we Justices must confront what is indeed an awesome responsibility. It has been rendered the solemn duty of the Supreme Court of the United States, laid upon it by Congress in pursuance of the Federal Government's power " $t \mathrm{t}] \mathrm{o}$ regulate Commerce with foreign Nations, and among the several States," to decide What Is Golf. I am sure that the Framers of the Constitution, aware of the 1457 edict of King James II of Scotland prohibiting golf because it interfered with the practice of archery, fully expected that sooner or later the paths of golf and government, the law and the links, would once again cross, and that the judges of this august Court would some day have to wrestle with that age-old jurisprudential question, for which their years of study in the law have so well prepared them: Is someone riding around a golf course from shot to shot really a golfer? The answer, we learn, is yes. The Court ultimately concludes, and it will henceforth be the Law of the Land, that walking is not a "fundamental" aspect of golf."

"A law can be both economic folly and constitutional."12

Next consider a few extra-judicial examples (which are often even better):

"If we're picking people to draw out of their own conscience and experience a "new" Constitution, we should not look principally for good lawyers. We should look to people who agree with us. When we are in that mode, you realize we have rendered the Constitution useless."13

"If the current society wants to outlaw discrimination by sex, hey we have things called legislatures, and they enact things called laws. You don't need a constitution to keep things up-to-date. All you need is a legislature and a ballot box." 14 content/dam/files/centers/boisi/pdf/Symposia/Symposia\%202010-2011/Constitutional_ Interpretation_Scalia.pdf.

14 Interview by $\bar{C}$ alvin Massey with Justice Antonin Scalia (Jan. 2011) available at http:// www.callawyer.com/2011/01/antonin-scalia.
} 
"If you think aficionados of a living Constitution want to bring you flexibility, think again. You think the death penalty is a good idea? Persuade your fellow citizens to adopt it. You want a right to abortion? Persuade your fellow citizens to enact it. That's flexibility." ${ }^{15}$

"Bear in mind that brains and learning, like muscle and physical skill, are articles of commerce. They are bought and sold. You can hire them by the year or by the hour. The only thing in the world not for sale is character." 16

"What is a moderate interpretation of the text? Halfway between what it really means and what you'd like it to mean?"'17

Finally, I will relate a personal anecdote. It was 1999 and I was working at a very good law school in Dunedin, New Zealand. A colleague and friend from a different New Zealand law school had organized a conference in Auckland and had invited Justice Scalia, who would be attending. I went too. Now I could tell you how, of all the judges speaking at that conference, it was only Scalia who volunteered for a special question and answer session with the Auckland law school students, and who stayed until there were no more questions. Or I might relate how much fun it was to find myself in a bar alone with my conference organizing friend, and with Scalia, with the latter making fun of his own short size and telling some great jokes while the three of us had a drink or two. But instead let me recount the session I witnessed at that Auckland conference, where Justice Scalia was on the same panel as a then Supreme Court of Canada Justice. The Canadian judge went first, and gently criticized as 'ancestor worship' any form of constitutional interpretation that relies on some form of originalism, preferring what we might today label a 'living tree'18 or 'living Constitution' interpretive approach. With hundreds of lawyers and judges in the room Scalia went up the podium when his turn came, put down his prepared talk, and proceeded to rebut the Canadian judge's claims, point by point. He was scathing and unremitting. I still recall Scalia looking at the Canadian judge and saying something along the lines of: "Of course I have no doubt that in Canada the judges have superior moral sentiments and feelings to mere plumbers or secretaries. But let's be clear that this is what my Canadian friend's approach boils down to - feelings, nothing more than feelings. In the US, those of us who are originalists on our top court do not believe we have superior moral and political feelings to everyone else."

It was a tour-de-force. I suspect the experience was also something of a shock for a top Canadian judge as in my native Canada, and I daresay in Australia, New Zealand and Britain, the top judges get used to being treated as lesser Gods, unctuously deferred to (not least by law students and lawyers who sometimes do so in ways that might qualify as 'Uriah Heepesque'), and not often criticized in public by anyone -

15 Scalia, supra note 13.

16 Justice Antonin Scalia, Commencement Address, Address at Commencement Exercises, College of William and Mary (May 12, 1996).

17 Scalia, supra note 13.

18 This phrase was made famous, in the Westminster common law world, by Lord Sankey in the Privy Council case from Canada of Edwards v. Att'y-Gen. for Can. [1930] AC 124 (PC). This 'living tree' term is the broad equivalent outside the United States for what Americans describe as a 'living Constitution' approach. 
and especially not by barristers, top lawyers, lower level judges, and rarely even by politicians for that matter. It struck me at the time that it would be a lot better and healthier for a legal system (especially those with a bill of rights where judges have more scope to gainsay the elected legislature) if top judges did have to face such public criticism - and I include vigorous criticism - on a more regular basis, and hence have to defend their views. Certainly Scalia appeared perfectly at home taking as much as giving. In fact, he seemed to revel in the vigorous exchange of views. I doubt there existed a kitchen anywhere whose heat could have forced Scalia out.

Of course that sort of combative style and attitude makes it very unlikely that Scalia would excel at consensus building, in the way that, say, Justice Brennan did on the Supreme Court of the United States. ${ }^{19}$ And indeed he did not. Scalia excelled instead at the biting dissent (including dissenting alone). Alan Morrison and Robert Stein put that same general point in these two ways:

Whenever one dissents, whether in a judicial decision or a faculty committee, a choice must be made between attempting to narrow the majority's decision or pointing out its potentially apocalyptic consequences. Justice Scalia has chosen the second option as his preferred choice in most cases. ${ }^{20}$

As an ideologue, Justice Scalia preferred his subjectively "correct" answer to the most mutually agreeable answer. Justice Scalia cites his adherence to originalism and textualism as the reason for his inability to form coalitions. Another, perhaps pettier, view suggests that Justice Scalia isolated himself by attacking his colleagues ... [though] Scalia responded, "You really think my colleagues are going to mess up American law because they are peeved at me?...."21

Now some will consider an unwillingness to move from what one sees to be the 'glass full' correct position in order to win supporters for a 'glass half full' position that is a less bad outcome than what would otherwise result to be foolhardy, in evolutionary terms perhaps even to be an ultimately 'loser proclivity'. Others will disagree and consider the judge's job description not to include hefty dollops of compromising and backroom negotiating with the other Justices - perhaps for core Rule of Law reasons tied to thinking the law's meaning is not dependent on (or at least ought not to be dependent on) shifting coalitions of judges' bargained-for votes, or perhaps for reasons tied to long-term rule-utilitarian calculations that put a big emphasis on democracy. Whichever position happens to attract you the reader, it is clear that Scalia fell into the latter camp. He was a great dissenter, not a backroom coalition builder.

19 See, e.g., Robert Stein, Foreword: A Consequential Justice, 101 Minn. L. Rev. 1-11 (2016) arguing that Brennan was much, much more adept at building a majority coalition of justices than was Scalia.

20 Alan Morrison, Remembering Justice Antonin Scalia 101 MinN. L. Rev. 12, 21-2 (2016).

21 Stein, supra note 19, at 9 (internal note to Scalia's 2015 Stein Lecture at the University of Minnesota omitted). 
And I am myself much more partial to that 'great dissenter' sort of judge. Put aside for the moment the more substantive issue of what sort of judicial philosophy one wants from his or her ideal top judge and focus on the periphery, on how one wishes a top court judge to respond to other top judges who appear not to be convinced by your ideal judge's reasoning in some case. In that situation I prefer my judicial common law world to be broadly inhabited by dissenting Scalias rather than negotiating, coalition-building Brennans..$^{22}$ In Australia, where I live and work, there are two very good recent examples of big dissenters on the country's top court, the High Court of Australia, both of whom are now retired. One is Dyson Heydon. In his last couple of years on the High Court he dissented at a very high rate indeed. ${ }^{23}$ Another is Michael Kirby, also someone known for dissenting. In terms of their approaches to constitutional interpretation and public law decisionmaking more generally, the substantive issue, I am very much a fan of Heydon and a critic of Kirby. ${ }^{24}$ But I nevertheless recognize that the odd Kirby or two every century on a top court might be a good thing ${ }^{25}$ - for John Stuart Mill free speech type reasons related to the benefits of being criticized and sharpening your own arguments as well as on other grounds too. Likewise with Lord Denning, to take a British example of a great dissenter, and irrespective of whether you are an admirer of the Denning modus operandi or not. ${ }^{26}$

22 For my considered view on the type of judge to appoint to a top court in the common law world see both James Allan, The Travails of Justice Waldron in EXPounding THE Constitution: Essays in Constitutional Theory (Grant Huscroft, ed., 2008), 161-83 and James Allan, Is Talk of the Quality of Judging Sometimes Strained, Feigned or Not Sustained? in Judicial InDEPEnDENCE IN Australia 64-75 (Rebecca Ananian-Welsh \& Jonathan Crowe eds., 2016). I note in the latter of those that the qualities of one's ideal top judge are one thing and what you want on an ideal top court another, such that we might not want that ideal top court staffed solely by nine clones of our ideal top judge. The analogy here is with imagining you had won a lottery where the monies had to be spent on one ideal house. Then imagine you had won a lottery where the monies had to be spent on two houses. In the latter instance, few if any people would buy a second home that was a clone of the first one. The criteria you brought to the task of buying two houses would differ, possibly wildly so, from those you brought to buying one. As regards the world's Scalias, then, the general point is that those who like the Scalia approach to judging still might not wish to have nine Scalias on their ideal top court while those who are not overly enamored with the Scalia approach might nevertheless think that the odd Scalia through time is quite beneficial to a top court. Of course this argument applies more widely than just to Scalia-type judges. For a brief discussion that covers some of the same dissenter v. coalition-builder ground see Jeremy Waldron, Temperamental Justice, N.Y. Rev. Books, 15-7 (May 10, 2007).

23 Justice Dyson Heydon authored 45\% of his judgments in dissent in 2011 and $40.43 \%$ in 2012. Andrew Lynch \& George Williams, The High Court on Constitutional Law: The 2012 Statistics, 36(2) U. New S. Wales. L. J. 359, 522 (2012).

24 See, e.g., my The Three " $R$ "s of Recent Australian Judicial Activism: Roach, Rowe and (no) 'Riginalism, 36 Melbourne U. L. Rev. 743. (2012).

25 See A Public Conversation on Constitutionalism and the Judiciary between Professor James Allan and the Honourable Michael Kirby, 33 Melbourne U. L. Rev. 1032-57 (2009).

26 I have a strong memory of a saying to the effect that 'Having a Denning on a top court is fine, you just wouldn't want more than one a century'. I was quite sure it had been said by a top British judge. But I cannot find the source of it, not even after asking a number of people I thought would know in the U.K., the U.S. and here in Australia. They too think they recognize this aphorism but cannot place its author. If I am wrong about it being someone else's invention, I will happily claim it for myself. 


\section{Constitutional Interpretation: Scalia the Originalist}

Turn now from Scalia the biting, funny judge not afraid to file (or perhaps unleash) a dissenting opinion and consider his approach to constitutional interpretation. This is a top judge who once said: 'I am not so naïve (nor do I think our forbears were) as to be unaware that judges in a real sense "make" law. But they make it as judges make it, which is to say as though they were "finding" it - discerning what the law is, rather than decreeing what it is today changed to, or what it will tomorrow be. ${ }^{27}$ And extracurially he claimed that:

Every issue of law resolved by a federal judge involves interpretation of text - the text of a regulation, or of a statute, or of the Constitution. Let me put the Constitution to one side for the time being, since many believe that that document is in effect a charter for judges to develop an evolving common law of freedom of speech, of privacy rights, and the like. I think that is wrong - indeed, as I shall discuss below, I think it frustrates the whole purpose of a written constitution. ${ }^{28}$

That purpose, for Scalia, was to lock certain things in, say bicameralism or a federal division of powers or a set of rights that set a new floor level of treatment of citizens below which the legislature could not drop. So Scalia thought that statutes and the constitution ought both to be interpreted in the same way, using a method he called 'textualism'29 but which (in the context of constitutional interpretation) is more commonly dubbed 'originalism' or 'new originalism' or 'original public meaning' or 'OPM' ${ }^{30}$ Here is how U.S. legal academic Larry Alexander describes this broadly Scalia-type school of constitutional interpretation:

The original public meaning view of originalism asks the interpreter of legal texts to seek the meaning that a reasonable member of the public at the time of the text's promulgation would have given the text. The interpreter is not to seek the authorially-intended meaning. There are two basic rationales the proponents of this version of originalism give for preferring it to the authorially-intended meaning of originalism. One rationale is that the original public meaning view avoids the problem of discovering that a law means something other than what most people think it means. The other rationale is that the original public meaning view avoids the aggregation problem, the problem posed by legal texts whose authors, who are multiple, have different intended meanings. ${ }^{31}$

\footnotetext{
27 James B. Beam Distilling Co. v. Georgia 501 U.S. 529, 549 (Scalia, J.) (1991) (emphasis in the original).

28 Scalia, supra note 3.

29 See, e.g. id. at 23. Scalia is clear that this does not mean strict constructionism (id. at 23), that 'context is everything' (id. at 37) and that what we seek to find is 'how the text of the Constitution was originally understood' (id. at 38).

30 For a full and excellent discussion of the topic see The Challenge of Originalism: TheoRies of Constitutional Interpretation (Huscroft \& Miller ed., 2011).

31 Larry Alexander, Legal Positivism and Originalist Interpretation, 16 Revista Argentina de TeOria Juridica 1-10, 3 (2015).
} 
As I signaled at the start of this article, I do not find Scalia's OPM version of originalism to be convincing (though it must be conceded that in the United States this Scalia-favored strand of 'new originalism' seems now to be the dominantly subscribed to or supported version of originalism). In their separate chapters in The Challenge of Originalism book ${ }^{32}$ both Larry Alexander and Stanley Fish set out powerful (and for me wholly convincing) arguments for why 'old originalism' or 'Original Intended Meaning' or searching for the authors' intended meaning is the preferable strand, and indeed why it is the only coherent version of originalism. ${ }^{33}$ In brief, there are two core problems with the OPM version of originalism. First off, in asking how the Constitution was originally understood OPM originalists end up having to construct some hypothetical member of the public or reasonable person back at the time the legal text came into force. You create an artificial, fictitious person - a rough contemporary of the actual authors - and ask yourself what this hypothetical member of the public, at that time, would have taken the text to mean (which is why there is a concern for the standard meaning of the words back at the time the Constitution was framed and ratified). But there is simply no non-arbitrary way to construct such a hypothetical person. Put differently, there is a spectrum of reasonable people (all differing in their general knowledge, IQs, linguistic fluency, where they lived, political attachments, and so on and so forth) and these different hypothetical people, each possessed of different information, may well interpret the same legal text differently. Choosing between them is just arbitrary. Worse, one suspects that for most people who construct a 'reasonable person' or a 'well-informed person at the time' touchstone that this hypothetical being will end up looking a lot like the person doing the constructing, be it in terms of range of knowledge, political leanings, value hierarchy, you name it. You are more than likely to construct someone an awful lot like you. Afterall, few people see themselves as anything other than reasonable.

The second problem is at least as telling. Real life OPM adherents may tell us that the meaning of some provision in the Constitution depends upon what some hypothetical, well-informed, reasonable person at the time (call him 'Jim', or probably back then 'James') would have taken the words to mean. But how would this James back then have gone about interpreting the legal text, remembering that he is not some literalist, strict constructionist and that the bare words - as Stanley Fish continually shows - will not often, if ever, be constraining? Would this James have sought the real-life actual authors' intended meanings of the text (since fictional James could not have been seeking his own preferred meaning)? But if fictional James is looking at the intended meanings of the real life authors then we, today, might as well cut out this made up Jamesian middle man and look at the real life ratifiers' and framers' intentions ourselves. Or would the fictional James, in all those penumbral or hard

32 Huscroft \& Miller, supra note 30.

33 Alexander's chapter begins at 87 and Fish's at 99 in this book. In addition to Alexander and Fish there are other powerful exponents of OIM or old originalism, most notably Richard Kay in the U.S. and (in the context of a jurisdiction with an unwritten constitution, so everything in a sense is statutory interpretation) Richard Ekins in the U.K.. In Canada any sort of originalist is an endangered if not extinct species, save in federalism disputes where even Supreme Court of Canada Justices (who otherwise are wholly dismissive) become originalists. 
cases, have constructed his own fictional, hypothetical, reasonable person James II? And likewise James II would have constructed James III ad infinitum?

So given these two core problems with OPM originalism why is it that all originalists are not (or no longer are) authors' intentions or Original Intended Meaning or old originalists? Certainly Scalia unequivocally rejects the relevance of the real life 'drafter's intent as the criterion for interpretation of the Constitution' ${ }^{34}$ Larry Alexander, after dismissing as wrong-headed two other concerns about original intentions originalism, concedes that there is a very real problem with this OIM interpretive approach. It is the group intentions problem, or as Alexander put it in the passage above, the aggregation problem. How do you deal with legal texts that were collectively authored? It is this, argues Alexander, that pushed people away from OIM originalism into the arms of OPM originalism. By positing but one hypothetical person back at the time of the law's passage you niftily avoid the group intentions problem. But as noted above, this cure is a good deal worse than the disease. It is worse than the group intentions disease because while attributing a single intention to a group is a problem, overwhelmingly it is not an insuperable one (while the OPM problems are). Certainly groups can and do have shared intentions (as any symphony-goer can attest, or any team sports fan can too after watching his favorite team execute a complicated play). In addition, albeit more so in the Westminster parliamentary world than when it comes to the U.S. Congress, there are evolved practices such as a Minister's Second Reading speech before the passage of a government Bill that allows us most times to say that these - the Minister's intentions - are what all who voted in favor intended. ${ }^{35}$

Within the broad church that is originalism, then, I think Scalia was in the wrong denomination. He had it wrong. He should have sought the meaning of the US Constitution in the actual intended meanings of the real life people who framed and ratified it, not in 'how it was originally understood' ${ }^{36}$ by some non-actual person at the time. He ought to have sought his external interpretive constraints where Alexander and Fish and Kay and Ekins seek theirs.

However, let me for a moment put to one side that intra-familial originalism debate and focus instead on the differences originalists (broadly speaking) have with non-originalists (broadly speaking). I want to do this because my goal in this article is to explain why I liked Scalia as a judge. Yes, as I set out in Part I, he was funny and biting and blunt and a great dissenter, and I liked that. But in this Part II it is Scalia's approach to constitutional interpretation that is our focus. And the question one needs to ask of non-originalist approaches to constitutional interpretation which runs the gamut from 'living tree' or 'living Constitution' approaches through Dworkinian Herculean 'best fit' approaches ${ }^{37}$ through moral reading approaches and even takes in Posnerian 'can't help it' or 'don't invalidate unless it fails the puke test' approaches ${ }^{38}-$ is from where do the external constraints come? Given the

\footnotetext{
34 A MATTER OF INTERPRETATION, supra note 3, at 38.

35 For a book length treatment of OIM as it applies to legislatures, see Richard EKIns, THE Nature of Legislative Intent (2012), and especially 161-79 where he details the U.K.'s House of Commons' elaborate procedures for enacting statutes.

36 See supra note 29.

37 See Ronald Dworkin, Taking Rights Seriously (1977).

38 Richard Posner describes (approvingly) O.W. Holmes's approach in just these terms. See The Problematics of Moral and Legal Theory, 111 HARV. L. REV. 1638, 1709 (1998)
} 
fact of reasonable disagreement, a disinterested outside observer would not find a top judge's claim to be constrained by what is most moral, or by what best fits with the settled materials, or by what is most in keeping with changing social values, or by asking what makes him want to puke to amount to mind-independent constraints on that interpreter. ${ }^{39}$ With these non-originalist interpretive approaches, to say there is an external-to-you constraint on the answer you have to reach would not be convincing. Hence, if you worry about judicial usurpation or judicial activism, and very much desire the interpreting judges to be constrained by something outside of their own moral and political and pragmatic sensibilities, then non-originalist approaches will not obviously be all that appealing to you.

Originalism, by contrast, asks you to look to external historical facts to find your answer, and so that answer might (and sometimes will) be one you dislike morally or politically or on efficiency grounds. Put differently, if we are to put much stock in rule of law values then the answers dictated by the legal norms must sometimes differ from the answers the point-of-application interpreter (the judge) would like them to be if he or she were legislating or writing a constitution from scratch. Non-originalist interpretive approaches make this distinction - between A) what the most plausible interpretation of the legal text happens to be and B) what I, the interpreter, would like the answer or outcome to be - extremely precarious. Indeed, Ronald Dworkin found it notoriously difficult to point to U.S. Supreme Court decisions that were in his view rightly decided (according to his own interpretive theory, or theories) and yet which had reached decisions he thought were morally and politically wrong. ${ }^{40}$ If, like me, you believe the distinction between A) and B) is a crucially important one in a democratic society, ${ }^{41}$ then any non-originalist interpretive theory will be less attractive to the extent you think it undermines the distinction and gives judges significant leeway (from an outside observer's vantage, if not seen or admitted by the interpreting judges themselves) to impose their own preferred outcomes - to legislate from the bench. ${ }^{42}$

(and at note 148) and 2004 Term Foreword: A Political Court, 119 Harv. L. Rev. 31, 84 (2005). And you could include a literalist, strict constructionist approach here too, as the mere words themselves without recourse to authors' intentions, are not constraining, for all the reasons Stanley Fish gives in note 33.

39 And as Jeremy Waldron has noted, this is true even if it turns out that we live in a moral realist world rather than a non-cognitivist or moral sceptic world when it comes to the status of moral evaluations. In other words, even if there is a mind-independent truth to moral claims, we limited biological human beings cannot know for certain what those truths are, so reasonable disagreement kicks in all the same even if moral realists be right. See Jeremy Waldron, The Irrelevance of Moral Objectivity in NaturaL Law Theory: Contemporary Essays 158-87 (Robert P. George, ed., 1992).

40 James Allan, Charles Fried, \& Ronald Dworkin, "The Supreme Court Phalanx": An Exchange, N.Y. REv. Books. (2007). Here I wrote a letter asking Dworkin to name a case as per the main text.

41 I say this, and strongly desire it, while also conceding that in extreme examples of egregious moral wickedness - examples I believe arise only exceptionally rarely in a democracy - then the right moral thing for a judge to do can be to lie. For me the argument pans out in consequentialist terms; it is even easier to make the case if you are a deontologist.

42 For OIM originalists the external constraint is provided by evidence of what the real life authors of the legal text look to have intended based on the historical evidence that can be found. Yes, there will be times when the evidence is far from conclusive. And yes, if the 
But rather than read how I put the case against non-originalist interpretive approaches, here is small taste of how Scalia himself puts it:

It seems to me that a sensible way of approaching this question is to ask oneself whether the framers and ratifiers of the Constitution (or of the Fourteenth Amendment) would conceivably have approved a provision that read somewhat as follows:

In addition to the restrictions upon governmental power imposed by the Bill of Rights, the States and the federal government shall be subject to such additional restrictions as are deemed appropriate, from time to time, by a majority of the Judges of the Supreme Court.

To pose that question is to answer it. ${ }^{43}$

And that takes me back to Scalia's preferred OPM branch of originalism and my preferred OIM branch. Notice two things. Firstly, Scalia's OPM interpretive approach could, and did, throw up cases where his preferred political and moral outcome differed from what he read the Constitution as dictating. In other words, the above distinction between A) and B) is alive and well for Scalia, and I very much like that fact.

At times, [Scalia's] personal beliefs clashed with his originalism. In Texas v. Johnson [491 U.S. 397 (1989)] in which the Supreme Court held that the First Amendment protected flag burning, Justice Scalia joined Justice Brennan's majority opinion. Left to his personal beliefs, Justice Scalia

cost of finding this evidence is too high (including in time or due to policy-related reasons such as wanting to force legislators to make laws in clear English or not wanting to force litigants to troll through the legislative record at great expense every time they go to court) then you might opt to restrict the allowable search for it. See Larry Alexander \& Saikrishna Prakash, "Is That English You're Speaking?" Why Intention Free Interpretation Is an Impossibility, 41 SAN DIEGo L. Rev. 967 (2004). On this tangentially related issue, I have argued in the past that you can distinguish constitutional interpretation from statutory interpretation in situations where you are deciding whether to put those sort of policyrelated restrictions on the search for authors' intended meaning. I am more open to such restrictions vis-à-vis statutory interpretation than constitutional interpretation because there is much, much more scope for the legislature to respond to them and say 'you judges got our meaning wrong by using these rule of law enhancing restrictions on the search for actual intentions, so we have passed a new, clearer statute'. You basically can never do that with constitutional interpretation situations as amendments almost never happen. So the ability to respond to the imposition of some 'let's advance rule of law concerns or try to keep costs contained' rule that in fact gets the intended meaning wrong will be much lower, if it exists at all, in the context of constitutional interpretation. In my view that means you might strike a different balance as regards constitutional interpretation than you would as regards statutory interpretation. See James Allan, Constitutional Interpretation v. Statutory Interpretation: Understanding the Attractions of "Original Intent", 6 LEG. THEORY 109-126 (2000).

43 Antonin Scalia, Romancing the Constitution: Interpretation as Invention, in Constitutionalism in the Charter Era, 337-44, 341 (Grant Huscroft \& Ian Brodie eds., 2004. All seven and a half pages, brimming with wit and vigor, are well worth reading. 
has stated that he would throw all flag burners in jail. ${ }^{44}$ But his originalist reading of the First Amendment broadly protects freedom of speech and, therefore, Justice Scalia's personal preferences succumbed to his ideological adherences [or as I would put it, to an interpretive approach that could impose answers that differed from those first-order preferences] ${ }^{45}$

Secondly, although I think Scalia's OPM branch of originalism is ultimately wrongheaded and unconvincing compared to the OIM branch (for all the reasons sketched out above), it is also the case that when it comes to legal texts (as opposed to, say, a James Joyce novel or a T.S. Eliot poem) the authors overwhelming use words in their standard sense. Write a constitution and you want to be understood in as transparent a way as possible, and so use language in its standard, conventional sense. ${ }^{46}$ No one drafting a constitution, or a statute, sets out for a bit of word play. What the drafters and ratifiers intend is very, very likely to align - not just with what some single hypothetical well-informed person at the time would have taken the words to mean but indeed - with what virtually all well-informed people at the time did take them to mean. Yes, there will be a few peripheral cases where the OPM approach will surreptitiously have to appeal to actual authors' intentions to reinforce some standard dictionary definition or to buttress why one meaning is to be chosen over another, but mostly these two branches or denominations of originalism will give the same answers as to what the Constitution means. As Richard Kay notes more generally, ${ }^{47}$ the alternative line of thinking - that conventional or public meaning has somehow diverged from, or more accurately put here, has taken on something near the exact opposite sense of, the intended meaning - requires you to posit a giant screw-up on behalf of the authors.

My larger point is that whenever we are talking about a relatively benevolent liberal democracy (so not, say, apartheid South Africa), I much prefer Scalia's approach to constitutional interpretation to the various non-originalist alternatives. Of course I think he's in the wrong denomination of originalism. But I like his approach miles better than all the 'living tree'/'living Constitution' and moral reading-type alternatives that clearly dominate, say, the European Court of Human Rights, the Supreme Court of Canada in all its Charter of Rights litigation, many of the recent SCOTUS majority opinions, and even some of the recent constitutional interpretation in Australia, where they lack any sort of national bill of rights and so you might have hoped for more. ${ }^{48}$

So in addition that is another reason I liked Scalia as a judge. He is, or rather was, considerably better than almost all of the alternatives today on offer. As a Scalian might say, it takes a theory to beat a theory, and the burden is not to prove originalism is flawless or perfect but simply to show it is better than the alternatives.

2015 Stein Lecture, October $20^{\text {th }}, 2015$, University of Minnesota.

Stein, supra note 19, at 8 (internal notes omitted).

46 There will be legal terms of art, as well, but these will be used in their conventional, standard legal senses at the time.

47 See Richard Kay, Original Intention and Public Meaning in Constitutional Interpretation, 103 N.W. U. L. REv. 703 (2009).

48 Supra note 24. 


\section{Scalia and the Scope for Democratic Decision-Making}

To start this Part III it might be desirable to make a confession. I think the best way, or rather the least-bad way, to make large scale social policy decisions is by counting all citizens or residents equally and voting for representatives. These elected parliamentarians or members of Congress will then in turn have an equally weighted vote as to whether their jurisdiction might, say, change the status quo when it comes to abortion, euthanasia, same-sex marriage, and so on. I very much believe it to be a bad thing when unelected judges make these calls, as they regularly have and continue to do, including in the United States and my native Canada. ${ }^{49}$ Scalia was against this trend towards ever more powerful judges or judicial usurpation. $\mathrm{He}$ liked democratic decision-making, and did not believe that the U.S. Bill of Rights had an ever-expanding scope or reach or ambit, one that allowed more and more issues to be resolved by unelected judges like him. No, Scalia believed that the inroads into parliamentary sovereignty (or into what the elected branches could and could not do) were locked in at the time the constitutional provision was adopted. That is what originalism delivers, a locked-in new floor below which the legislature may not descend but above which reform or change depends on voting and lettingthe-numbers-count. The reach of some enumerated list of rights, for Scalia, did not after adoption grow or expand its reach or metaphorically become 'alive' based on what nine ex-lawyer top judges happened to believe were changing social values.

The people are not stupid. When the primary function of the Supreme Court was thought to be interpretation of text and identification of legal tradition, the people were content to have justices selected primarily on the basis of legal ability. But they know that Harvard Law School, Stanford Law School - yea, even Yale Law School - do not make a man or woman any more qualified to determine whether there ought to be a right to abortion, or to homosexual conduct, or to suicide, than Joe Six Pack. ${ }^{50}$

How many of today's top common law judges think like that, have that respect for democratic decision-making, and are skeptical of too great judicial power? Well, we all know the answer is far, far too few. Jeremy Waldron speaks of this aspect of Scalia's comparative unusualness in this way:

It is worth noting however that this hunger for power does not seem to afflict all judges. Even in a system of strong judicial review, like that of the United States, there are judges who are very diffident about - well, that's too mild: some are ferociously opposed to - exercising the final power of decision over moral and political issues on which citizens and their representatives disagree. Some of them are influenced in this by their awareness of citizens' resentment of judges' arrogation of this power. Consider, for example, Justice Antonin Scalia's dissent in the great 1992

49 I make this argument at length in Democracy in Decline: Steps in the Wrong Direction (2014).

50 Scalia, supra note 43, at 343. 
abortion case, Planned Parenthood v. Casey. ${ }^{51}$ Discussing "the "political pressure' directed to the Court: the marches, the mail, the protests aimed at inducing us to change our opinions," Justice Scalia advised his fellow-justices to consider "the twin facts that the American people love democracy and the American people are not fools." .... The comment has to be understood in terms of the context of American constitutionalism, and Scalia is not an opponent of judicial review as such. But he is alert to the threat that it poses to democracy, not only by empowerment of people (judges) who, in many cases, ought not to be so empowered, but also by the way in which juristocracy truncates affirmatively valuable processes of political decision-making. Again, a dissent from Scalia, this time from the gay marriage case of Obergefell $v$. Hodges,${ }^{52}$ makes the point quite well:

Until the courts put a stop to it, public debate over same-sex marriage displayed American democracy at its best. Individuals on both sides of the issue passionately, but respectfully, attempted to persuade their fellow citizens to accept their views. Americans considered the arguments and put the question to a vote. The electorates of 11 States, either directly or through their representatives, chose to expand the traditional definition of marriage. Many more decided not to. Win or lose, advocates for both sides continued pressing their cases, secure in the knowledge that an electoral loss can be negated by a later electoral win. That is exactly how our system of government is supposed to work. ${ }^{53}$

To my way of thinking Waldron is wholly correct. Yes, there are other top common law judges out there who are opposed to juristocracy or kritarchy or 'judges as Philosopher King final decision-makers' or call it what you will. Yes, there are others opposed to this 'Hero Judge' role,$^{54}$ true. But not all that many others. Far too many of today's top judges - and yes, I specifically include top judges in the U.K. and the U.S. - either convince themselves that 'proportionality'-type analyses are not empowering them to the extent an outside observer can clearly see that they are, or implausibly believe that there is some sort of robust 'dialogue' going on with the legislature that limits their last-word power, or actually quite welcome both their power to settle contentious social issues (by majority 5-4 top court judicial vote, as it happens) as well as, more generally, welcoming their restraining power over mere elected politicians. Scalia was not one of those sort of judges. The Supreme Court of the United States, and therefore the country as a whole, was the better for it.

This, then, is yet another reason for my praising Antonin Scalia the top judge. He had more trust in the voters and the democratic process than the vast preponderance of other common law top judges operating in a system with an entrenched bill of rights. ${ }^{55}$

505 U.S. 833 (1992).

576 U.S. (2015) at 2 of the slip opinion.

53 Jeremy Waldron, "Who Wants Juristocracy?" Who Indeed? IN The SEARCh FOR Certainty: Essays in Honour of John Smillie 14-5(Shelley Griffiths et. al. eds., 2016) (internal notes omitted).

$54 \quad$ See John Gava, The Rise of the Hero Judge, 24 U. New S. WaLes L. J. 747 (2001).

55 And note that in my view the U.K.'s Human Rights Act, or statutory bill of rights, has empowered the top judges to an extent that rivals judicial power in the U.S. and 


\section{Concluding Remarks}

It should be plain to all readers by now that I was a fan of Scalia the judge. I would gladly have put his clone on to the High Court of Australia, or on to the Supreme Court of Canada, or indeed back on to the Supreme Court of the United States. By my way of thinking it is extremely unlikely that Scalia's replacement will measure up to the judge he or she is replacing - not in terms of wit, humor and quality of dissents; not in terms of the interpretive theory this replacement brings to the job; not in terms of a core respect for the voters' choices; and notwithstanding whether the replacement is nominated by a Democrat or a Republican.

By contrast, most law professors in the U.S. - and possibly more again in Canada, the U.K., Australia and New Zealand - will see just about any replacement for Scalia as an improvement. A major reason for that, in my view, is that many law professors quite like a solid measure of judicial activism or "social progress through the unelected judges' and are not overly trustful of the choices that would be made by a majority of their fellow citizens. ${ }^{56}$ Call this preference one for a modern day form of aristocracy if you wish. But if I am right, and this view pervades the legal academy, then it would be a brave punter who bet against its being passed on to the next generation of lawyers, probably in even more virulent form.

I find that prospect pretty depressing. I think Scalia did too.

Canada. See my Statutory Bills of Rights: You Read Words In, You Read Words Out, You Take Parliament's Clear Intention and You Shake It All About - Doin' the Sankey Hanky Panky in The Legal Protection of Human Rights: Sceptical Essays 108-26 (Tom Campbell et.al. eds., 2011).

56 That is the kind way of putting it. A less kind way would be to say that they are openly elitist, preferring the quality of decisions lawyers and judges fashion to those of the great unwashed. In short, they believe that strong judicial review delivers the goods, and teach their students accordingly. 